\title{
鋼構造梁端混用接合部の力学性能に関する実験的研究 \\ A STUDY ON THE STATICAL CHARACTERISTICS OF THE WBFW TYPE BEAM TO SHS COLUMN CONNECTIONS
}

\author{
增田浩志*，田中淳夫**，銭鋼*** \\ Hiroshi MASUDA, Atsuo TANAKA and Gang QIAN
}

\begin{abstract}
In this paper the experimental study on the statical characteristics of WBFW (web bolted and flange welded) type WF beam to SHS column connections are described. The main experimental factors are $\mathrm{D} / \mathrm{t}$ ratio of SHS column (16 and 28 ), the disposition of bolts at web connection (CO, CS and CB: see Fig.2). From this experimental study it becomes clear that D/t of SHS column should be smaller than nearly 20 when the maximum bending strength of the beam end connection is required larger than $1.2 \mathrm{Mp}$ (Mp: full plastic moment of the connected beam). The maximum bending strength of the web bolted connections may have small influence upon the maximum bending strength of beam end connections, but has large influence upon the plastic deformation ability of the connected beams.
\end{abstract}

Keywards : beam to column connection, WBFW type connection, maximum bending strength, plastic deformation ability 柱梁接合部，混用接合部，最大曲げ而力，塑性変形能力

\section{1.はじめに}

䤡棈造物における柱と梁の接合方法は一般に梁端部を工場溶接す るブラケット形式の接合と，ウェブを高力ボルト摩擦接合し，フラ ンジを現場溶接する梁端混用接合に分けられる。梁端混用接合は梁 端部付近での収まりがよいことと梁の接合部の数が少なくできると いう経済的な理由から広く用いられるようになっているが，フラン ジとウェブの接合法が異なっているため, ブラタット形式の接合に 比へてて，接合部における応力伝達は複雑なものとなっている．また， 梁の接合部の設計において，従来は曲げはフランジ接合部分で，せ ん断力はウェブ接合部分で負担すると仮定して設計することが慣用 的であったが，梁断面が大きくなると梁ウェブ部分の曲げ負担が大 きくなるため,この部分でもある程度の曲げ耐力を負担できるウェ ブ接合部分の設計が必要であるとの観点から，筆者らは，梁端混用 接合について，柱材に $\mathrm{H}$ 形断面材，箱形断面材を用いて実験を行い， ウェブ接合部分の接合部の耐力レベルによって期待できる梁端接合 部の耐力と塑性変形能力に差が生じること, 特に箱形断面柱を用い た場合には柱の径厚比の影響を受けることを報告した（参考文献 1). しかし, 本学における従来の研究は, 梁の鋼材としてSS400 材を用いたものだけであり，他の研究機関で行われたSM490材を梁 に用いた実験結果 ${ }^{3) \sim 9)}$ と幾分異なった結果が得られている。そこで， 梁端混用接合部の適切な設計を行うために必要な基碳資料の蓄積を
目的として,さらにSM490材の梁を用いた場合についても実大実験 を行った．本論文はその実験結果についてまとめ, 更に, これまで に得られた多くの実験結果とあわせて梁端混用接合部の耐力評価法 についてより詳細な検討を行うものである。

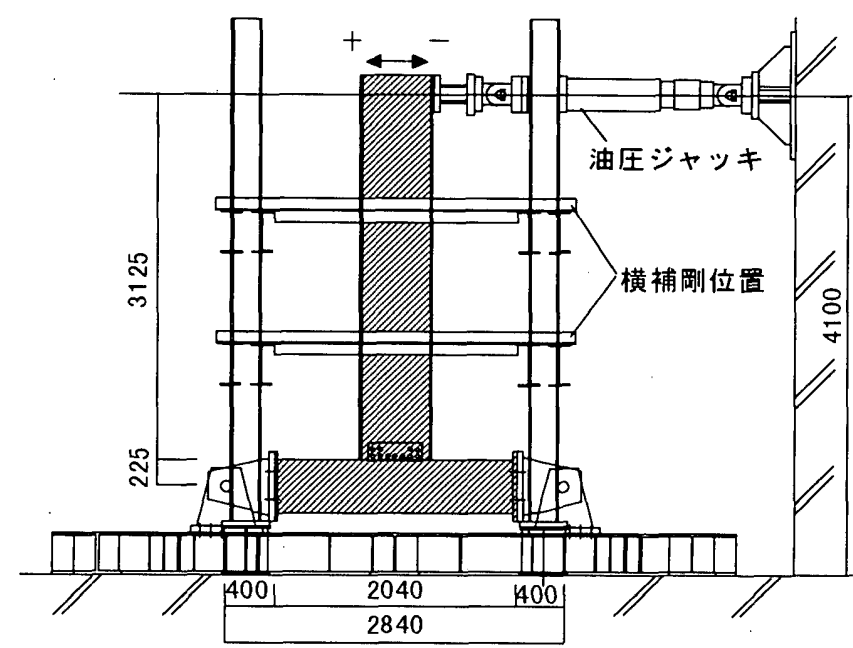

図1試験体形状と加力状況
* 宇都宮大学 助手.工修

**宇都宮大学 教授・工博

*** 構造計画研究所 博士 (工学)
Research Assoc., Department of Architecture, Utsunomiya University, M. Eng. Prof., Department of Architecture, Utsunomiya University, Dr. Eng. KOZO KEIKAKU ENGINEERING Inc., Dr. Eng. 


\section{2. 败験㖕画}

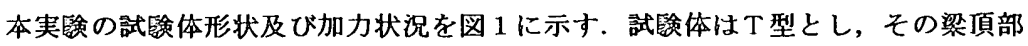
に油圧ジャッキによる正負湔增繰り返し水平荷重を作用させる，加力は弾性域で繰 り返した後， $\pm 2 \delta \mathrm{p} ， \pm 4 \delta \mathrm{p} ， \pm 6 \delta \mathrm{p} ， \pm 8 \delta \mathrm{p}$ を基準に変位制御とした。 $\delta \mathrm{p}$ 端が全塑性モーメントに達する荷重に堼応する加力点位㯰の水平変位の計算値であ る. 試験体に用いた柱, 梁はそれぞれ 2 㮐類である. 本研究では, ウェブ接合部分 のボルトの配列及び柱の径厚比の遠いが接合部の耐力, 変形能力に与える影響を主 な稌封項目とする，柱は450mm角の椧間成形角形銅管 (BCP325) で板厚を $16 \mathrm{~mm}$ (C28 と呼ぶ:28は径厚比を表す)と $28 \mathrm{~mm}$ (C16と呼ぶ)とし，梁はC28の柱には600×200×11 $\times 17$ の圧延 $\mathrm{H}$ 形鈎， $\mathrm{C} 16$ の柱には $600 \times 300 \times 12 \times 22$ の容接組立H形斨面材を用い

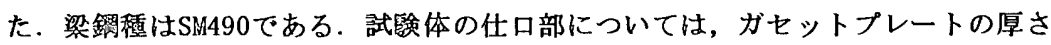
を一定とし，ウェブ接合部分のボルト配置をせん断力の伝達のみを考慮して設計し た場合 (1列配置·CSと乎ぶ) と曲げの伝達まで考虑して設計した場合 (2列または3列 配置·CBと呼ぶ)の 2 種碩の試釦体を設定した．また，フランジ接合部分のみによる

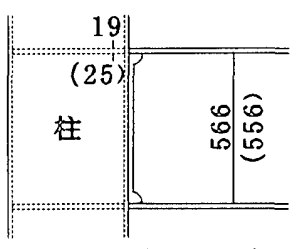

$\mathrm{C} 28-\mathrm{CO}(\mathrm{C} 16-\mathrm{CO})$

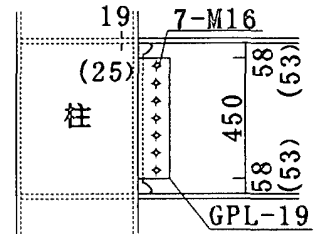

$\mathrm{C} 28-\mathrm{CS}(\mathrm{C} 16-\mathrm{CS})$

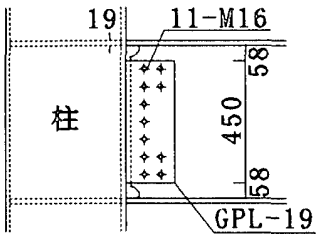

$\mathrm{C} 28-\mathrm{CB}$

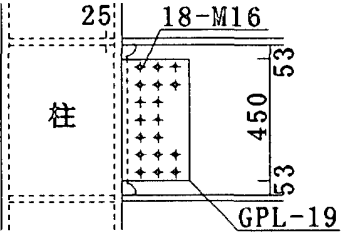

$\mathrm{C} 16-\mathrm{CB}$

\section{图 2 接合部苇細}

最大曲げ耐力を倹討するために，ウェブを全く接合していない試鍳体（COと呼ぶ）も用意した．試 虞体の一覧及び耐力計算值を表 1 に示寸。ここに示した柱材，梁材の全塑性モーメントMpは表 2 に 示す素材試鍳結果による降伏応力度を用いた計算值である．Muは接合部全体の最大曲げ耐力であ り, bMwu，bMgu，bMBu，cMmpはそれぞれ梁ウェブ接合部分の曲げ負担領域を考虑した梁ウェブ

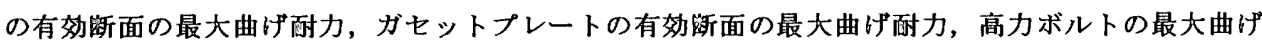
耐力, 柱スキンプレートの面外曲げ降伏による最大曲け淂力であり，bQwuとbQBu惊，せん激力負 担領域の梁ウェブ接合部分の最大せん断酎力と高力ボルトの最大せん断耐力であり，Xは曲げ負担 領域である、それらの数值の計算方法は，この形式の梁端接合部の㓦力を詳細に険討し，関連する 耐力式を提示した参考文献2)に示した所による，なお，ウェブ接合部分の最大曲け㓦力の算定式は 付録に再録した.

フランジ接合部の溶接は炭酸ガスアーク半自動溶接とし，柱を立てて上下フランジとも上から下 向きに行った．またウェブ接合部分には高力六角ボルトを用い，その本締めは，ナット回捏法によ りフランジの容接に先立って実施した. 使用ボルトはM16(F10T) でボルトれのクリアランスは2m文 した．呼び径M16のボルトを用いたのは，梁ウェブのボルト接合部分の曲げ耐力にせん断力のみを想 定して設計したものと，せん断力と曲げ㓦力を想定して設計したものとの間にボルト本数に明瞭な差 が生じるようにするためである. 各試験体の接合部の詳細を図 $2 \sim 4 k$ 示す. また，実僰に用いた各

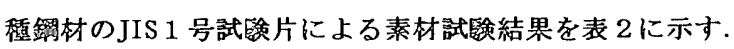

\section{3. 宊龭結器}

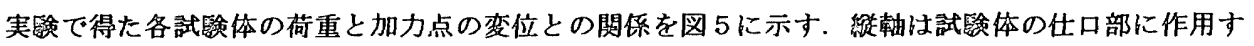
るモーメントMを素材試験結果による梁材の全塑性モーメントの計算值Mpで除して祭次元化した

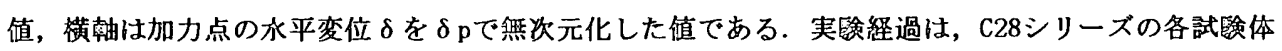
及びC16-C0では終局状態に至るまでは全試験体ともほぼ同椂で, まず, $\pm 4 \delta \mathrm{p}$ 時に圧薙側梁フランジ が局部座屈を起こし, その後引張側フランジ内側のスカラップ底に惫裂が生じ, 以後加カサイクル每 に皃裂が進展し，最終的に引張側フランジが跪性的に破断した。 C28-CS, CBはフランジ破断と同時に ウェブ接合部分のフランジに近い列のボルトも破断している。 C16-CS, CBは $\pm 6 \delta$ 時にスカラップ端 部に小さな急裂は生じたが, その後進展せずに最大耐力を示した後, 最終時まで破断は発生せずに加

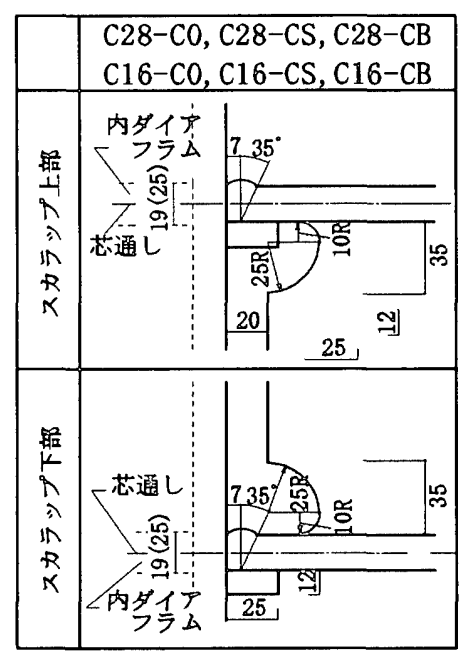

图 3 スカラップ部噼細

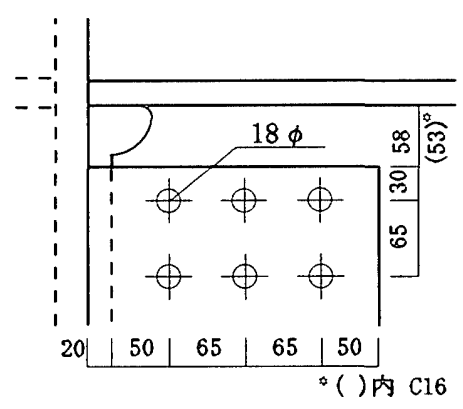

图 4 ボルト孔位置䛨細

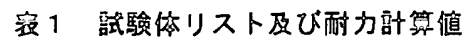

\begin{tabular}{|c|c|c|c|c|c|c|c|c|c|c|c|c|c|c|c|c|c|c|c|}
\hline \multirow{3}{*}{$\begin{array}{l}\text { 試蹒 } \\
\text { 体名 }\end{array}$} & \multirow{3}{*}{$\begin{array}{c}\text { 梁征面 (mm) } \\
/ \\
\text { 柱断面 (mm) }\end{array}$} & \multirow{3}{*}{$\begin{array}{c}\text { 材質 } \\
\text { 梁/柱 }\end{array}$} & \multirow{3}{*}{$\begin{array}{c}\mathrm{Mp} \\
\mathrm{tfcm} \\
\text { 㳅/柱 }\end{array}$} & \multirow{3}{*}{$\begin{array}{l}\mathrm{Mu} \\
\mathrm{tfcm}\end{array}$} & \multirow{3}{*}{$\begin{array}{l}\text { bMøu } \\
\text { tfcm }\end{array}$} & \multirow{3}{*}{$\begin{array}{l}\mathrm{bMgu} \\
\mathrm{tfcm}\end{array}$} & \multirow{3}{*}{$\begin{array}{r}\mathrm{bMBu} \\
\mathrm{tfcm}\end{array}$} & \multirow{3}{*}{$\begin{array}{l}\mathrm{cM} \text { wp } \\
\mathrm{tfcm}\end{array}$} & \multirow{3}{*}{$\begin{array}{c}\mathrm{bQ} \text { स } \\
\mathrm{tf}\end{array}$} & \multirow{3}{*}{$\begin{array}{c}\mathrm{bQBu} \\
\mathrm{tf}\end{array}$} & \multirow{3}{*}{$\begin{array}{l}X \\
\mathrm{~cm}\end{array}$} & \multicolumn{8}{|c|}{ ウェブ接合部分詳細 } \\
\hline & & & & & & & & & & & & \multirow{2}{*}{$\begin{array}{l}\text { ボ虾 } \\
10 \mathrm{~T}\end{array}$} & \multirow{2}{*}{$\begin{array}{ll}\mathrm{tg} \\
\mathrm{mm}\end{array}$} & \multirow{2}{*}{$\mathrm{m}$} & \multirow{2}{*}{$\mathrm{e}$} & \multirow{2}{*}{$\mathrm{g}$} & \multicolumn{3}{|c|}{ ボルト本䫓と配置 } \\
\hline & & & & & & & & & & & & & & & & & 1 列 & 2 列 & 3 列 \\
\hline $\mathrm{C} 28-\mathrm{CO}$ & $\mathrm{H}-600 \times 200$ & SM490/ & 11666 & 11001 & 0 & 0 & 0 & 0 & 0 & 0 & - & \multicolumn{8}{|c|}{ ウェブ接合せず } \\
\hline $\mathrm{C} 28-\mathrm{CS}$ & $x 11 \times 17 /$ & BCP325 & 1 & 11473 & 2159 & 2506 & 472 & 4369 & 116 & 61 & 14.4 & \multirow[t]{2}{*}{ M16 } & \multirow[t]{2}{*}{196} & \multirow{2}{*}{\multicolumn{2}{|c|}{\begin{tabular}{l|l}
65 & 50
\end{tabular}}} & - & 7 & - & - \\
\hline $\mathrm{C} 28-\mathrm{CB}$ & $\square-450 \times 16$ & & 18362 & 11945 & 2159 & 2506 & 944 & 4369 & 116 & 85 & 14.4 & & & & & 65 & 7 & 4 & - \\
\hline $\mathrm{C} 16-\mathrm{CO}$ & $\mathrm{BH}-600 \times 300$ & SM490/ & 17034 & 20142 & 0 & 0 & 0 & 0 & 0 & 0 & - & \multicolumn{8}{|c|}{ ウェブ接合せず } \\
\hline $\mathrm{C} 16-\mathrm{CS}$ & $x 12 \times 22 /$ & ВСР325 & I & 20929 & 2383 & 3076 & 787 & 4927 & 73 & 36 & 18.4 & \multirow[t]{2}{*}{ M16 } & \multirow[t]{2}{*}{$|19| \mathrm{c}$} & \multirow[t]{2}{*}{$655^{5}$} & \multirow[t]{2}{*}{50} & 二 & 7 & - & 一 \\
\hline $\mathrm{C} 16-\mathrm{CB}$ & $\square-450 \times 28$ & & 26367 & 22502 & 2383 & 3076 & 2360 & 4927 & 73 & 73 & 18.4 & & & & & 65 & 7 & 7 & 4 \\
\hline
\end{tabular}



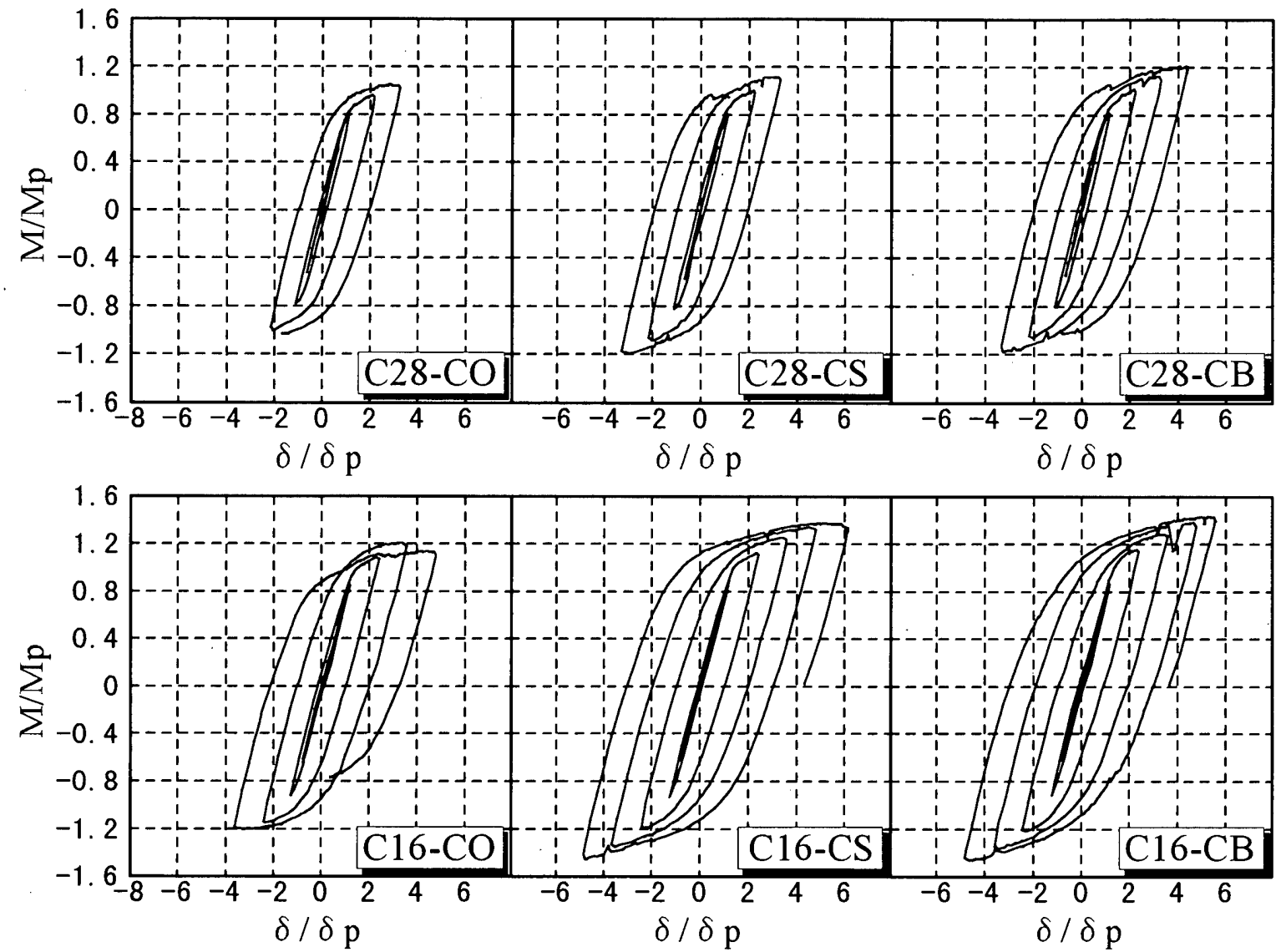

図 5 各試験体の $M / M p-\delta / \delta p$ 関係

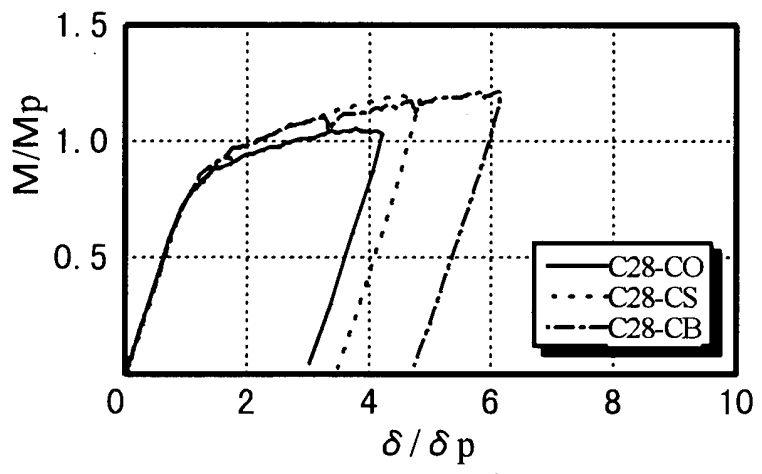

(a) C28シリーズ骨組曲線

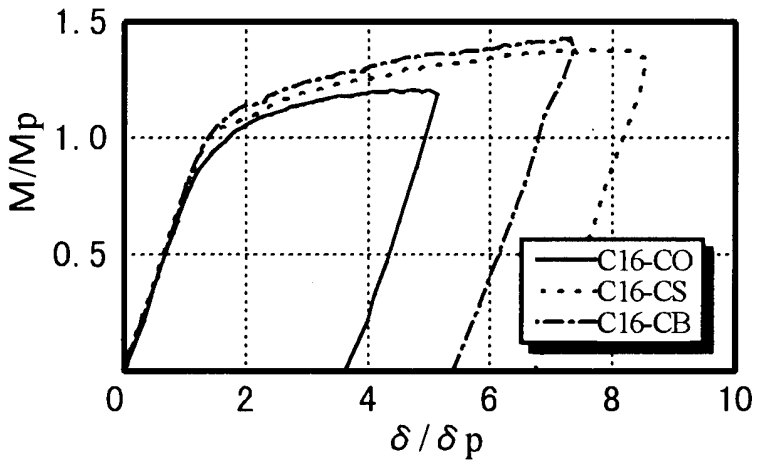

(b) C16シリーズ骨組曲線
表 2 鋼材の機械的性質

\begin{tabular}{|l|c|c|c|l|}
\hline 板材名 & $\sigma \mathrm{y}\left(\mathrm{tf} / \mathrm{cm}^{2}\right)$ & $\sigma \mathrm{u}\left(\mathrm{tf} / \mathrm{cm}^{2}\right)$ & 伸び(\%) & 備考 \\
\hline PL11 & 4.13 & 5.59 & 23.5 & ウェブ \\
\hline PL17 & 4.05 & 5.55 & 25.4 & フランジ \\
\hline PL12 & 3.56 & 5.22 & 26.1 & ウェブ \\
\hline PL22 & 3.60 & 5.28 & 27.6 & フランジ \\
\hline PLC16 & 4.06 & 5.33 & 24.9 & 柱 \\
\hline PLC28 & 3.52 & 5.31 & 28.1 & 柱 \\
\hline PL19 & 3.76 & 5.35 & 25.4 & ガセット \\
\hline
\end{tabular}

表 3 実験結果

\begin{tabular}{|c|c|c|c|c|c|c|c|}
\hline \multirow{2}{*}{$\begin{array}{l}\text { 試験 } \\
\text { 体名 }\end{array}$} & \multirow{2}{*}{$\begin{array}{c}\text { Pmax } \\
\mathrm{tf}\end{array}$} & \multirow{2}{*}{$\delta \underset{\max }{\delta}$} & \multirow{2}{*}{$\begin{array}{l}\text { eMu } \\
\text { tffem }\end{array}$} & \multirow{2}{*}{$\frac{\mathrm{eMu}}{\mathrm{Mp}}$} & \multicolumn{2}{|c|}{$\eta \mathrm{s}$} & \multirow{2}{*}{$\begin{array}{l}\text { 破断 } \\
\text { 部位 }\end{array}$} \\
\hline & & & & & + & - & \\
\hline $\mathrm{C} 28-\mathrm{CO}$ & 36.7 & 101 & 11469 & 0.983 & 2. 87 & 2.05 & 上* \\
\hline C28-CS & 41.6 & 116 & 13000 & 1.114 & 2. 87 & 3. 63 & 下* \\
\hline $\mathrm{C} 28-\mathrm{CB}$ & 42. 2 & 157 & 13188 & 1. 130 & 5. 13 & 3. 43 & 下* \\
\hline $\mathrm{C} 16-\mathrm{CO}$ & 61.3 & 112 & 19156 & 1. 125 & 3. 25 & 4. 10 & 上* \\
\hline C16-CS & 73.9 & 165 & 23094 & 1.356 & 8.73 & 6. 32 & - \\
\hline $\mathrm{C} 16-\mathrm{CB}$ & 74.4 & 168 & 23250 & 1.365 & 7.07 & 6.97 & - \\
\hline
\end{tabular}

* : 上, 下は破断したフランジを示す. 
力装置の能力限界に達したため実駼を終了した．梁のウェブを接合 していない試臨体のうち，梁に溶接組立材を用いた $\mathrm{C} 16-\mathrm{C} 0$ では最終 時に梁のウェブとフランジの隅肉溶接緵目がスカラップ部分から大 きな䒊裂を生し゚，その結果梁端で梁断面が当初の形状を保っていな い状況となっていた．主要な実験結果一覧を表 3 に示す．ここでPm

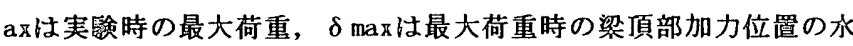

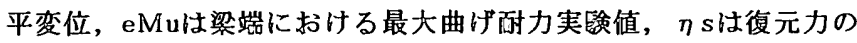
骨格曲線より求めた塑性変形倍率である。

4. 湾察

\section{(1) 淁合部の力学怪状}

実的で得られた復元力特性から求めた大きな変形を示した側の骨 格曲線を図 6 に, 梁端の最大曲げ耐力 $\mathrm{eMu}$ 梁の全塑性モーメント $\mathrm{Mp}$ で除した最大耐力係数 $\alpha$ と柱の径厚比 $\mathrm{D} / \mathrm{t}$ の関係を図 7 に，また $a$ と骨格曲線から得られた塑性変形倍率 $\eta \mathrm{s}$ の関係を図 8 に示寸.

1）径厚比の影留

図6より，C16シリーズとC28シリーズの試験結果を比べると柱の 径厚比の小さいC16試験体では，いずれも梁端のモーメントがMpに 達するまでほほ弾性的な举動を示しているが，C28試跧体はいずれ も $\mathrm{Mp}$ の 8 割程度の加力時から降伏現象が認められる. 柱の径厚比 が大きくなると梁ウェブが取り付く角形鈞管フランジ部の面外曲げ 甽性が小さくなるためウェブ接合部分の曲け抵抗も小さくなり，結 果として部分架荤の降代現象にも影響を及ぼしていることが指摘で きる.図 7，8より同椂のボルト配置の場合，C16とC28を比べると 柱の径厚比が小さいC16の方が $a ， \eta \mathrm{s}$ ともに明らかに大きい值を示 しており,これより柱の径厚比が接合部の最大耐力, 部分架模の変 形能力に与える影瑤は大きいといえる．柱の径厚比に対する最大耐 力の低下の状況が前報と同様に線形䦎係にあると考えると，ウェブ を接合している場合，eMuが1. $2 \mathrm{Mp}$ 確実に超えるにはD/tを22〜2 3以下とする必要があると思われる.

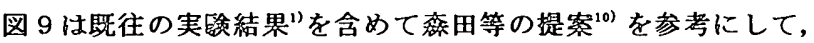
箱形断面柱の梁ウェブとの接合部における面外変形を考盧して求め た梁ウェブの曲げ応力負担領域 $\mathrm{X}^{2}$ を梁成Hで除した值と柱径厚比 $\mathrm{D} / \mathrm{t}$ との係をプロットしたものである．この図より $\mathrm{D} / \mathrm{t}$ とウェブ接合 部分における曲げ負担領域比X/Hはほ直線的な関係にあり， D/tが 20程度の箱形所面柱を用いた場合には，梁ウェブ接合部分の曲げ応 力負担領域X海の上下に扔いて，それぞれ梁成の 3 割程度に相当 すると推定される。

2）ボルト眍置の影嵒

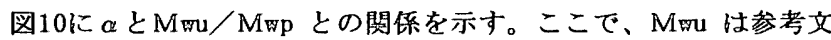
献2)に示した評洒式による梁ウェブ接合部分の最大曲げ耐力の計算 值であり、Mmpは材料試殹結果による降伏応力度を用いて計算した 梁ウェブのみの全塑性モーメントである。また、図10には、以前に 本学で行った梁端混用接合部の実瞼結果（B12, B19シリーズ）"に ついての同樣な関係も示した。

この図より、梁のウェブを全く接合していない試嗆体とウェブを

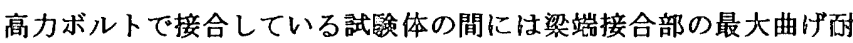
力に明らかな差が認められ、梁端接合部の最大曲げ耐力を礁保する 上で、ウェブを接合することの必要性が改めて確認されたといえる。 一方、ウェブを接合している武鏂体についてみると、C16系列を除 いて柱の径厚比が大きくなるに従ってウェブ接合部分の最大曲げ耐

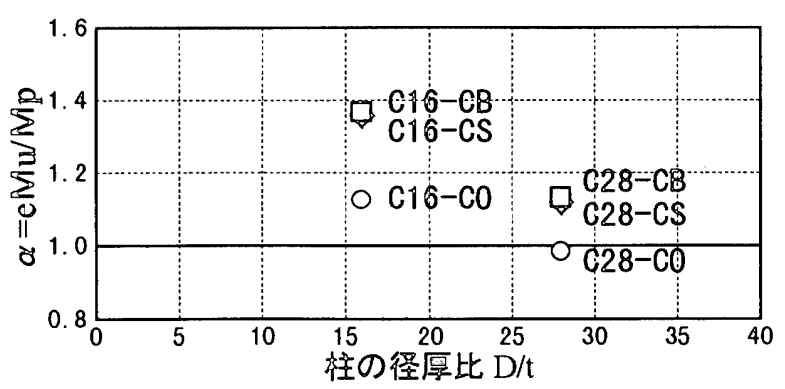

图 $7 \alpha-\mathrm{D} / \mathrm{t}$ 関係

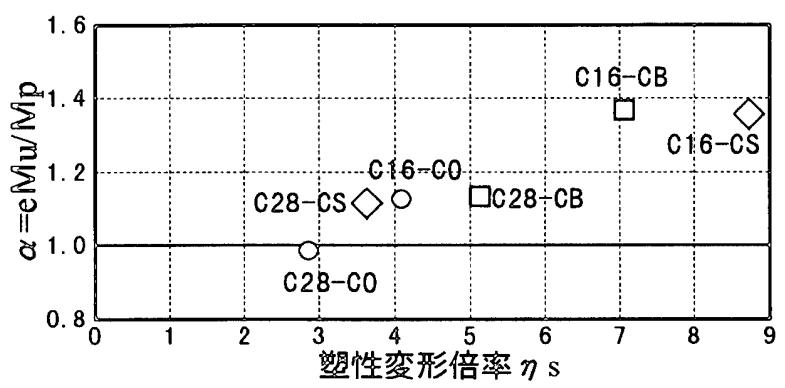

图 $8 \alpha-\eta$ s関係

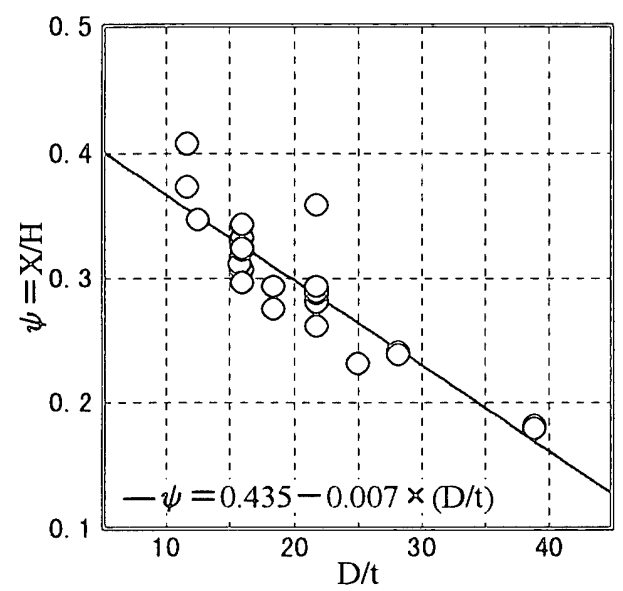

图 $9 \mathrm{X} / \mathrm{H}-\mathrm{D} / \mathrm{t}$ 閶係

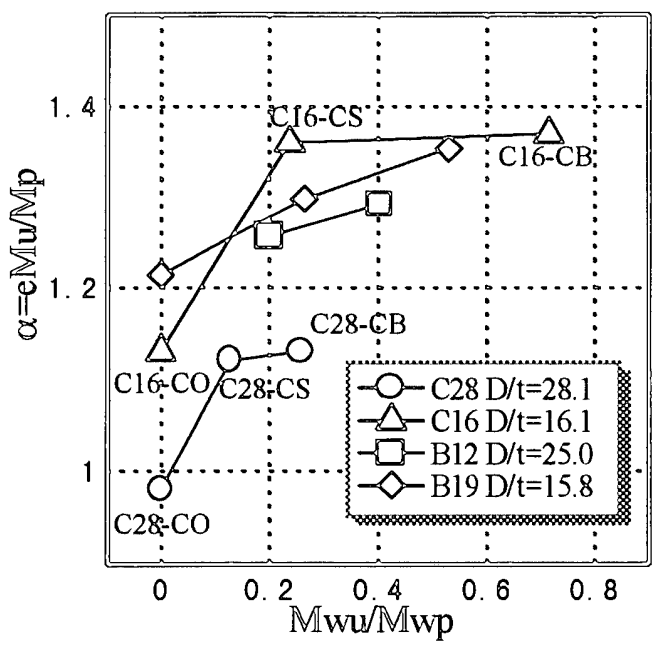

图10 $\alpha-M w u / M w p$ 
力の增大が梁端接合部全体の最大曲げ耐力の上昇に与える影響が小 さくなっていることが認められる。この点は、柱の径厚比が大きく なるに従ってウェブが接合されている柱のスキンプレートの面外曲 げ喇性が小さくなるため、ウェブ接合部分で伝達できる曲げ耐力が 小さくなる結果と思われる。C16系列については、梁材のフランジ 幅が梁成の $1 / 2$ と他の系列の試験体の $1 / 3 \sim 1 / 2.5$ に比べて大きいた め、梁全体の塑性断面係数に対するウェブの塑性断面係数の割合が 0.19 と他の試験体の0.3以上に比へてて格段に小さく、梁部材全体と しての曲げ耐力におけるウェブの曲げ耐力の割合が小さいこと、並 びに梁端接合部の最大曲げ耐力が梁材の全塑性曲げ耐力の 1.4 倍程 度と非常に高く、この値がこの種の接合部の最大耐力上昇率のほぼ 限界に達していると考えられることなどからウェブ接合部分の曲什 耐力の增大が接合部全体の最大曲げ耐力の上昇に結びつかなかった ものと思われる。図11に $\eta \mathrm{s}$ と $\mathrm{Mwu} / \mathrm{Mwp}$ との関倸を示寸. この図 より，C28シリーズの場合， $\mathrm{Mwu} / \mathrm{Mwp}$ \%上昇に伴い $\eta$ sは上昇して いることが認められる. C16シリーズでは，ウェブを接合していな いCOに比へて, CS, CBは塑性変形能力が上昇しているが, CSとCBの 間に本質的な差は認められない. 図 5 に示した試験体の荷重一変形 関係から判断してこれはC16-CS, CBが試験終了まで接合部で破断せ ず, 実験終了が加力装置の限界で決まったことの影智であると考え られる．C28-CSとC28-CBではウェブ接合部分での曲げ負担を考慮し たCBの方が曲げ負担を考慮していないCSに比へて塑性変形能力の点 では明らかに優れていることが虫められる。

図12は, 以前に本学で行った梁端混用接合部の同様の実験結果 ${ }^{1}$ であるが,この場合も柱に箱形断面材を用いた場合には $\eta \mathrm{s} の$ 最大 值は10程度となっている。

以上の検捨より, 塑性変形能力を確保するためにはウェブ接合部 分の最大曲け耐力を大きくとることが重要であるが，柱に箱形断面 材を用いた場合には $\eta$ sは10程度が限界になるものと思われる。

(2) 接合部の最大曲げ耐力

接合部の最大曲け耐力は下式で評価される.

$\mathrm{Mu}=\mathrm{Mfu}+\mathrm{Mwu}$

Mfuは, フランジ接合部分の最大曲げ耐力計算值であり，Mwuは ウェブ接合部分の最大曲げ耐力の計算值である. Mwuは, ウェブ材 の破断耐力, ガセットプレートの破断耐力, ボルトの破断耐力, 柱 スキンプレートの面外降伏耐力より求めた值の最小值となる. その 具体的な耐力評価法については参考文献2)に詳述してある.

\section{1) フランジ接合部分の最大曲げ耐力}

一昨年に本学で行った梁にSS400材を用いた同様の実験”において， フランジ接合部分のみの最大曲げ耐力を評価するために，今回と同 様ウェブ接合部分を全く接合しない試駼体について加力実験を行っ ている. その際の実験結果ではフランジ接合部分のみの最大曲げ耐 力の実験值 $\mathrm{eMu}$ 計算值 $\mathrm{Mfu}(=\mathrm{Zfp} \cdot \sigma \mathrm{fu} \quad \mathrm{Zfp}$ : フランジのみ の塑性断面保数， $\sigma \mathrm{fu}$ : 素材試験によるフランジ材の引張強さ) の 1.29倍となり, ウェブを接合した試験体の最大曲げ耐力の評価でも この值を用いることによってほぼ適正な耐力評価ができている”。

しかし, フランジ接合部分に関する実験値と計算值の比としてこの 值はかなり大きい值であり，既往の他の研究施設における実験結

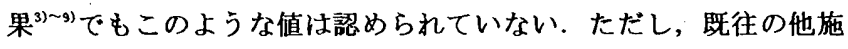
設での研究では, 梁材は寸べてSM490材で, SS400材の実験結果は

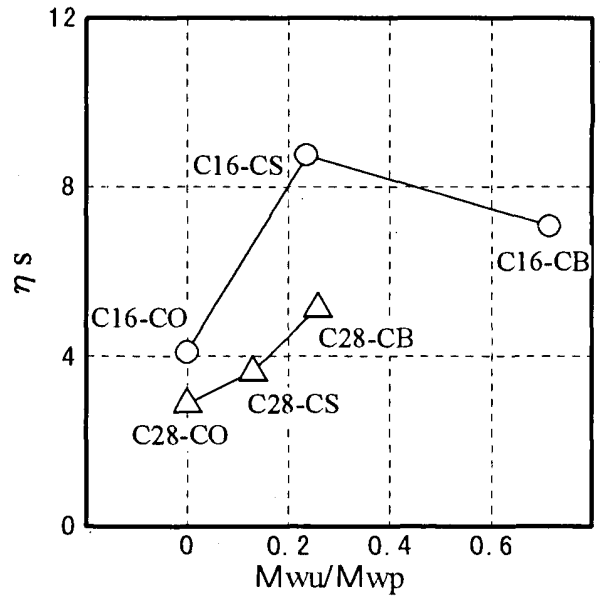

图11 SM490材の $\eta$ s-Mwu/Mwp

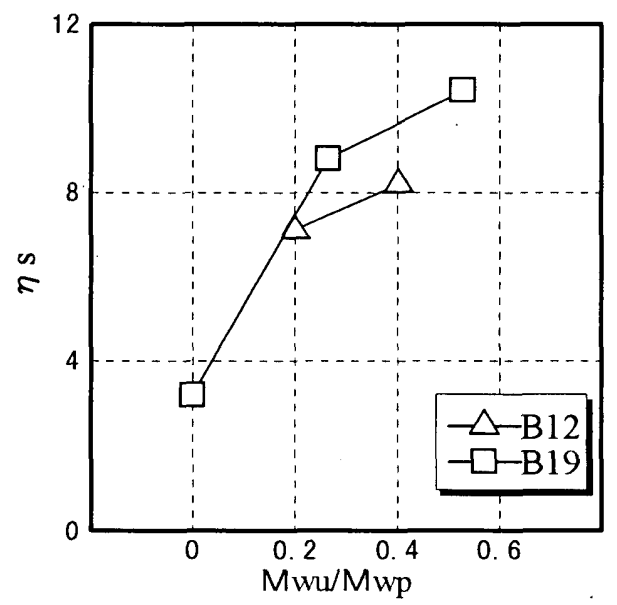

図12 ss400材の $\eta \mathrm{s}-M w u / M w p$

ない．そこで今回の実験において同様の試験体を用意して,この点 を検討することとした，C28-C0，C16-C0がそのための試験体である. C28-C0, C16-COについて eMu/Mfuを求めるとそれぞれ1.04，0.9 5となっている.このうちC16-C0については, 梁に溶接組立材を用 いたため, 実験結果でも述べたように, 最終時にフランジとウェブ の組立溶接がスカラッブ端から切れてしまい, 梁断面が当初の形状 を完全に保持することができていない. ウェブを接合している場合 には，このような破断形式は生じないと思われるので，C16-C0の最 大曲げ耐力は, ウェブを接合している場合のフランジ部分の最大曲 け耐力の実際の值を多少下回った值を与えているものと考えられる。 一方, C28-C0のeMu/Mfuの值は1.04であり，この程度の実験值は 特に問題となるような値ではない。

因みに前述のSS400材の梁を用いた同様の実験結果では、eMu / Mfuの值は1.29となっており、前報でこの点についてフランジ端の 溶接継目における幅方向および板厚方向の拘束の影響を考慮した比 較的単純な理論的検討を行っている ${ }^{2)}$ 。その検討結果によればフラ. ンジ接合部分の引張り強さの拘束効果による上昇率は、䤡材の降伏 比に関保し、次式で表されることとなる。

$$
\kappa=1.75 \sigma \mathrm{y} / \mathrm{\sigma u}
$$




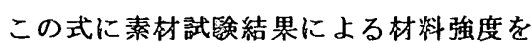
入れると前回の実験の場合、フランジ接 合部分の最大㓦力の上昇率は 1.18 とな る。C28-C0、C16-C0kついても同樣に険 討を行うと、フランジ接合部分の耐力上 昇率はそれぞれ1.27、1.19となる。この 值は明らかに寒虡值より大きく、更に梁 がSS400材の場合と逆の結果となってお り、上記の単純な理諭的詽価法が必ずし も妥当な結果を与えるものでないことが 判明した。つまり、前報で示した単純な 理諭的検討が不十分なものであったこと になる。従って、この点は今後更に検討 すべき浬題と考えられるが、フランジ接 合部分のみを对象とした実監データ及び 梁にSS400材を用いた実鍳データが少ない ため、本報ではこれ以上の検討は行わな W。

いずれにしても、梁にSM490材を用いた 今回の実唋結果は、他の研究機閣におけ る既往の赛験結果とも整合しており、か つ拘束勃果を考慮していない単純な理諭 値と実験值の間に大きな差は認められな い。従って、梁にSM490矿を用いる場合に は、フランジの容接接合部分において拘 束㜓果による応力上昇の影喓を特に考慮 する必要のないことが改めて確諰された ことになる。

2）ウェブ侤合部分の最大鮧げ而力

既往の実駼デーダを含めて参考文献2)に示した方法でウェブ接合 部分の最大曲げ耐力 $\mathrm{Mwu}$ 求め，ウェブ接合部分の最大曲げ耐力の実

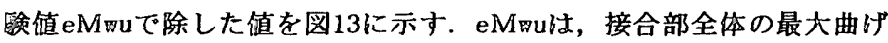

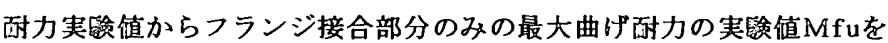
差し引いたものである。これをみると，今回の赛験結果では，従来の 実䟻結累に比べウェブ接合部分の最大曲げ酎力の実驗值が計算值より かなり大きくなっていることが認められる．今回の実䋡結果を含め

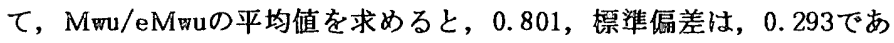
り，上述の評洒法によってウェブの耐力評価を安全僓に行うことがで きたが，かなりばらつきが大きいことが判る.

そこでこの点を検討するために，ウェブを溶接接合とした場合のウ エブ接合部分の最大曲げ俔力についても同椂の評価法を用いて倹討し てみる.ただし，この場合，ウェブの破壊モードは溶接部の破断，母 材破桓と柱スキンプレートの面外降伏のみであり，関連要因はボルト 接合とした場合に比べて少ない。ウェブを溶接接合とした場合につい て倹討する実験結果としては，表 4 に示す試駼体に関するものを対象

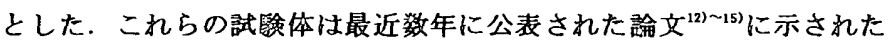
ものである。これらの試験体に関してウェブ接合部分の最大曲げ酎力 について，ボルト接合の試験体の場合と同樣の検討を行った結果は図 14に示寸通りである. $\mathrm{M}$ wu/ $\mathrm{eM}$ wuの平均値は0.970, 標準偏差は0.161 となっており，この場合もばらつきはみられるもののウェブを高力ボ

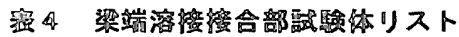

\begin{tabular}{|c|c|c|c|c|c|c|}
\hline $\begin{array}{l}\text { 本研究の } \\
\text { 試験体名 }\end{array}$ & $\begin{array}{l}\text { 原試験体名 } \\
\text { (参考文献) }\end{array}$ & $\begin{array}{l}\mathrm{Mu} \\
\mathrm{t} f \mathrm{~cm}\end{array}$ & $\begin{array}{l}e M w u \\
t f c m\end{array}$ & $\begin{array}{l}\mathrm{cMfu} \\
\mathrm{tf} \mathrm{cm}\end{array}$ & $\begin{array}{lll}c M & & u \\
t & f & c m\end{array}$ & $\begin{array}{l}\text { 梁材 } \\
\text { 材犋 }\end{array}$ \\
\hline A & $C 28-W B(11)$ & 12656 & 1655 & 11001 & 1902 & SM 490 \\
\hline B & C16-FB (11) & 23313 & 3171 & 20142 & 3038 & SM 490 \\
\hline $\mathrm{C}$ & $B-1(12)$ & 12610 & 2214 & 10396 & 1961 & SM 490 \\
\hline $\mathrm{D}$ & $B-0(1$ & 12150 & 1754 & 10396 & 1961 & SM 490 \\
\hline $\mathrm{H}$ & $\mathrm{RS}(13)$ & 17514 & 3413 & 14101 & 2441 & SM 490 \\
\hline$F$ & $\operatorname{RNS}(13)$ & 17820 & 3719 & 14101 & 3406 & SM 490 \\
\hline G & RNS-D(13) & 17964 & 3863 & 14101 & 3406 & SM 490 \\
\hline $\mathrm{H}$ & & 15390 & 2541 & 12849 & 3182 & SM 490 \\
\hline I & & 18162 & 5313 & 12849 & 4463 & SM 490 \\
\hline $\mathrm{J}$ & NS-1D $(1:$ & 19062 & 6213 & 12849 & 4463 & SM 490 \\
\hline$\underline{K}$ & T2-NS1(13) & 18936 & 5683 & 13253 & 4609 & SM 490 \\
\hline$\underline{\mathrm{L}}$ & TC-NS1(13) & 19422 & 6169 & 13253 & 4609 & SM 490 \\
\hline $\mathrm{M}$ & NB-S-5L (14 & 11520 & 1851 & 9669 & 2227 & SM 490 \\
\hline $\mathrm{N}$ & NB-R-5L (14 & 11961 & 2292 & 9669 & 2227 & SM 490 \\
\hline$\underline{O}$ & NB-R-5M (14 & 13086 & 2302 & 10784 & 2460 & SM 490 \\
\hline $\mathrm{P}$ & $B F-S-5 H(14$ & 12789 & 2078 & 10711 & 2437 & SM 490 \\
\hline Q & NB-R-5H (14 & 13221 & 2510 & 10711 & 2437 & SM 490 \\
\hline$\underline{\mathbf{R}}$ & NCB4 (15) & 14712 & 2032 & 12680 & 1725 & SM 490 \\
\hline$\underline{S}$ & SCB4 (15) & 14294 & 1614 & 12680 & 1725 & SM 490 \\
\hline $\mathrm{T}$ & SAG4(15) & 14224 & 1544 & 12680 & 1725 & SM 490 \\
\hline
\end{tabular}


ルル摩擦接合とした場合より平均值, ばらつきとも良好な結果となってい る.これは, 上述のように溶接接合の 場合の耐力評価における関連要因が少 ないことの影響であろう.

以上に述べたウェブ接合部分の最大 曲げ耐力に関する検討結果より, ウェ ブ接合部分の最大曲げ耐力の評価方法 として参考文献2)で述べた方法がほぼ 妥当なものと考えられるが, ウェブ接 合部分を高力ボルト接合する場合に は,ここを溶接接合する場合に比べて 関連する要因が多く，かつそれらの要 因が互いに影響し合うことも考えら れ，より精度の高い評価法を確立する ことは仲々難しい問題であると思われ るが、今後更に検討が必要であろう。

3）接合部全体の最大曲げ耐力

今回の実験を含めて本学で行った梁 端混用接合の試験体の最大曲价耐力M uを(1)式で計算し，これを実験值 $\mathrm{eMu}$ で除した值を図15に示す。この場合， 2)で述べたウェブ接合部分の耐力評価 の精度の関係で今回の実験結果に対し ては多少安全側の評価となっている が,すへての実験結果でみると $\mathrm{Mu} / \mathrm{e}$ $\mathrm{Mu}$ の平均値は, 0.982 , 標準偏差は, 0.068であり，精度がよく，汸らつき もあまり大きいものではないことが判る.

表 4 に示したウェブを溶接接合した梁端接合部についても(1) 式 によって接合部全体の最大曲げ耐力の計算値を求め, 実臨值と比較 した結果を図16に示寸. $\mathrm{Mu} / \mathrm{eMu}$ 平均値は 0.987 ，標準偏差は0.0 34であり，この場合も実験結果を精度良く評価していることが判る.

以上に述べた検討結果より，森田等の検討結果 ${ }^{10)}$ を参考として柱 のスキンプレートの面外変形を考慮して定めたウェブ接合部分の最 大曲げ耐力評価法”は，ウェブ接合部分が高力ボルト接合の場合に は, 溶接接合の場合に比べて関連する要因が多いため評価結果の精 度に不十分な点はあるが，ウェブ接合部分が負担する曲げが，接合 部全体の曲げ耐力の $10 \%$ 程度であるため，このウェブ接合部分の耐 力評価法を用いても, 接合部全体の耐力評価においては, 工学的に みて十分な精度が得られるものと判断される。

5. 結び

かねて懸案だったSS400材を用いた梁におけるフランジ接合部分 の最大曲け耐力が上昇した問題については，今回のSM490材を梁に 用いた実験ではそのような現象は見られず，前報で述べた単純な仮 定に基づいた理論的検哷が必ずしも妥当なものではなかったといえ る。この点はやはりSS400材を用いた実験によって再度検討すべき であろう.ただし，その場合を含めて(1)式で接合部の最大曲げ耐 力を評価することは明らかに安全側の評価を与えるものであり, 設 計上(1) 式を用いることは特に問題はないといえる. また，ウェブ

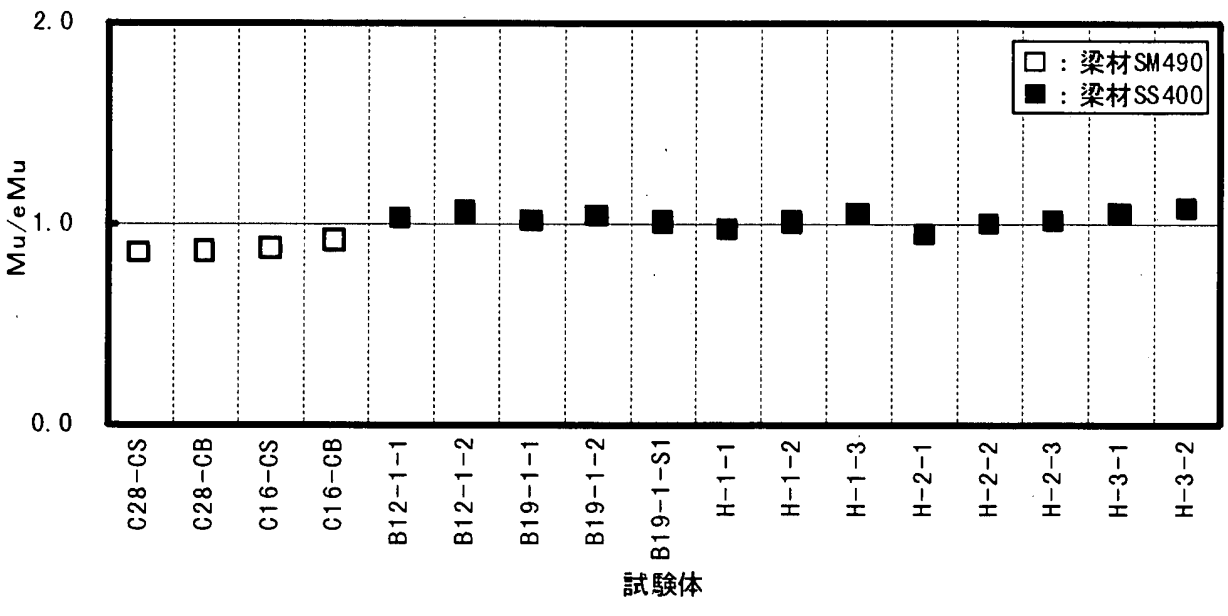

图15 混用接合部の最大曲げ柇カの評的

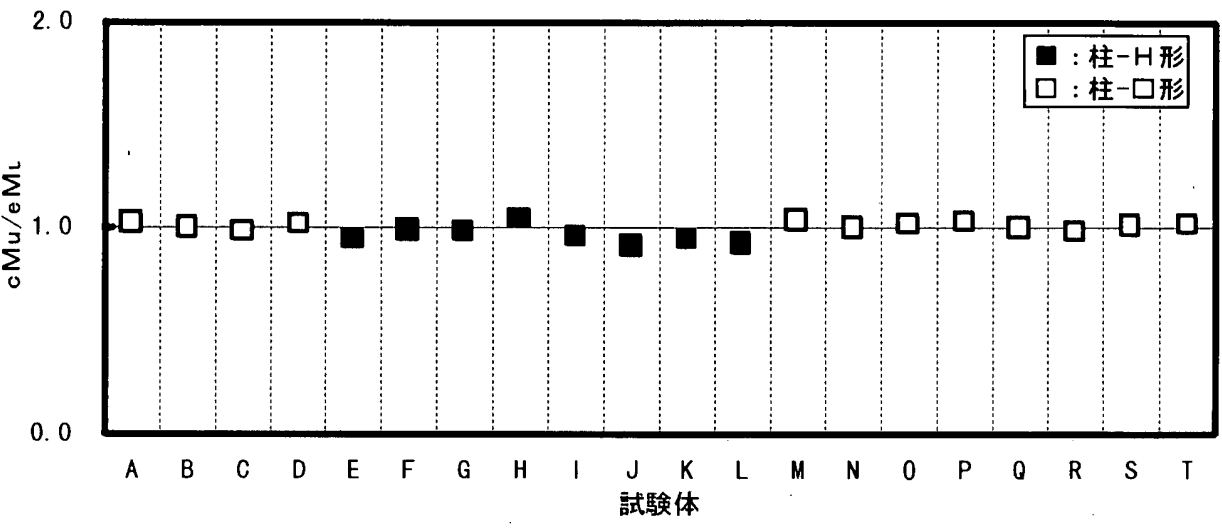

図16 溶接接合部の最大曲げ柇カの評任

接合部分の曲げ負担を考慮した梁端混用接合部の最大曲げ耐力につ いては，箱形断面柱の径厚比や梁断面形状の影響があるため，ウェ ブ接合部分でせん断耐力のみしか考慮しない設計による接合部と大 差ない場合もあるが，塑性変形能力の確保の面では明らかに貢献し ていると考えられ，ウェブ接合部分での曲げ負担を考慮した接合部 設計が望ましいと考えられる.

今回行った実験より梁端混用接合部の力学特性について明らかと なった点は以下の通りである.

・1.2Mp以上の接合部の耐力を確保するためには, 柱の径厚比の値 を22〜23以下に小さくする必要がある.

・ウェブ接合部分の曲げ耐力の増加に伴い接合部全体の最大曲げ耐 力は上昇するが，その上昇の程度はあまり大きいものではない， 箱形断面材の径厚比が大きくなるとこの㑯向はより大きくなるも のと考えられる.

・梁端混用接合部を有する部分架構の塑性変形能力は, 一般にウェ ブ接合部分の曲げ耐力を大きく設計した場合の方が大きくなる.

〈謝辞〉

本研究における載荷実験及びデータ整理については, 当時の卒 論生である石丸亮君，加々見信太郎君及び修士の学生であった 杉浦勝晃君の多大の協力を得た．哚く感謝する次第である. 


\section{參落立厥}

1）田中淳夫, 增田浩志, 高木大, 久田哲暗: 梅造梁端混用接合 部の力学性状に関する研究, 日本建築学会造系铪立集, 第48 4 号, pp. 121-130，1996年6月

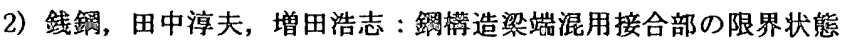
設計法と信頼性に関する研究，日本建築学会榙造系諭文集，第 501号, pp. 109-116，1997年11月

3）寺本隆幸, 㢇伊道夫, 関嘉男, 佐藤和彦, 田中清 : 箱型断面柱 に接合された $\mathrm{H}$ 形断面梁の曲げ酎力及び塑性変形能力に関する

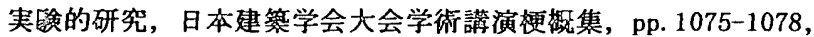
1986年8月

4）荻原伸治, 小福学, 竹下弘史, 泉满, 成原弘之 : ボックス柱に 取り付くウェブ蝠厚比の大きいH形断面のウェブ補強の実跧, 日本建筑学会学街潇演梗概集，pp. 1159-1160，1992年8月

5) 坂本真一, 矢部喜堂, 真䫤伸治 : 見場溶接接合型式の柱梁接合 部における $\mathrm{H}$ 形鎉梁端部の力学的性能, 日本建築学会模造系諭 文集 第456号，pp. 69-79，1994年2月

6）立山英二：現場溶接接合による H形銅柱·梁接合部の力学的性

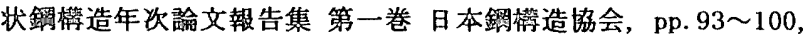
1993年7月

7）立山英二：現場溶接型柱·梁仕口部にお切る H形銅梁端部の力 学性状に関する実検的研究, 日本建築学会大会学街丵演梗概集, pp. 1277〜 1278，1993年9月

8）藤田哲也, 中込忠男, 田中一男, 鳴沢明雄 : 現場溶接型柱梁 溶接接合部の力学的珄能, 銅權造年次諭立報告集 第一巻 日本 銓權造協会, p. 101 p. 109，1993年7月

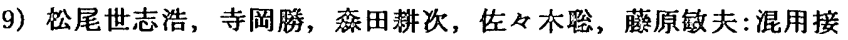
合形式の角形鐦管柱・H形整梁接合部に扔ける力学的举勁に与え

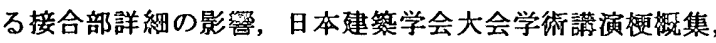
pp1473〜1476， 1994年9月

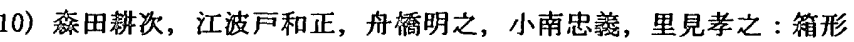
断面柱のかど溶接を部分溶込み溶接とした柱はり接合部の力学 的举動に開寸る研究, 日本建築学会權造系論立集, 第397号, pp. 48-59，1989年3月

11）石丸亮，加々見信太郎，田中淳夫，增田浩志：鍮權造梁端混用 接合部の力学性状に関寸る研究（その 1 ，その 2 ）日本建築学 会大会学術讙演梗概集，權造而pp. 429-432，1997年9月

12）真喜志卓, 山本昇, 禁田敖炊他：ノンスカラップ梁蝡接合部の

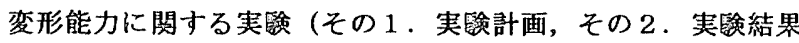
および考察)，日本建築学会大会学街丵演梗概集, pp. 1257$1260 ， 1993$ 年9月

13）中込忠男, 矢部喜堂, 坂本真一：梁スカラップの有無が箱形断 面柱に溶接接合される H形金梁端部の力学的珄状に及ぼす影海， 日本建築学会模造系諭文集，第432号，pp51-59，1992年2月.

14）山本昇, 石井匠, 森田敖次 : はり端溶接接合部の力学的举動に およぼすスカラップの影響, 模造工学論文集 Vol. 39B, pp493$506 ， 1993$ 年3月

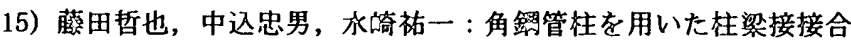
部の力学的性能に関寸る実敇的研究（梁スカラップの形状と溶 接時の目遠いが力学的性能に及ぼ才影縹），日本建築学会大会 学術羝演梗概集，pp-1537-1538，1992年8月

付睩

ウェブ接合部分の最大曲げ封力の算定式は，以下の通りである゙2.

MNu $=\min \{b M r u, b M g u, b M B u, c M m p\}$

$\mathrm{bMwu}=Z_{\text {we }} \cdot$ Oru

bMgu $=$ Zge $\cdot$ ogu

$\mathrm{bABu}=(\Sigma \mathrm{Lbi}) \cdot \mathrm{Rsu}$

$\mathrm{cMwp}=\mathrm{Zcp} \cdot \sigma \mathrm{cy}$

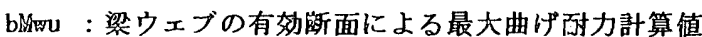

bMgu : ガセットブレートの有刹继面による最大曲げ耐力計算值

bMBu：高力ボルト接合による最大曲げ㓦力計算值

cMwp : 柱スキンブレートの面外降伏による最大曲げ酎力計算值

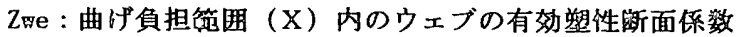

Oッu：梁ウェブ犲の引張強さ

Zge : 曲げ負担筑囲 (X) 内のガセットブレートの有効塑性断面俰 疑

ogu : ガセットプレート材の引張強さ

Rsu : 高力ボルト一本あたりの最大酎力

Lbi：曲げ負担筑用 (X) 内の各ボルトに対する応力中心間距蓶

Zcp：柱スキンプレートの面外降伏による塑性断面俰数 ocy：柱材の降伏応力度

（1997年 9 月 5 日原稿受理，1998年 2 月 13 日採用決定） 